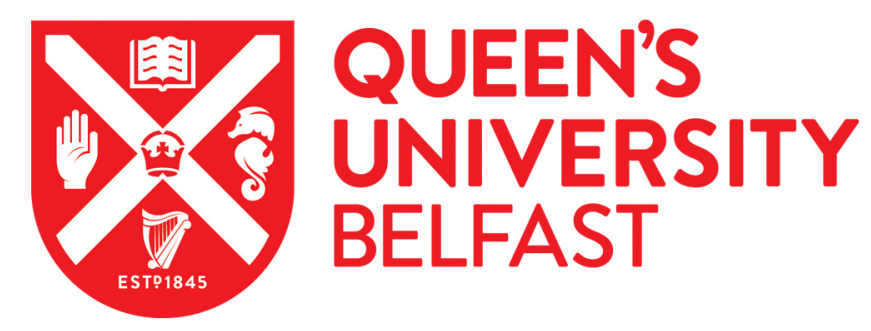

\title{
Borenium ionic liquids as catalysts for Diels-Alder reaction: tuneable Lewis superacids for catalytic applications
}

Matuszek, K., Coffie, S., Chrobok, A., \& Swadzba-Kwasny, M. (2017). Borenium ionic liquids as catalysts for Diels-Alder reaction: tuneable Lewis superacids for catalytic applications. CATALYSIS SCIENCE \& TECHNOLOGY, 7(5), 1045-1049. https://doi.org/10.1039/C7CY00106A

Published in:

CATALYSIS SCIENCE \& TECHNOLOGY

Document Version:

Peer reviewed version

Queen's University Belfast - Research Portal:

Link to publication record in Queen's University Belfast Research Portal

Publisher rights

Copyright 2017 RSC

This work is made available online in accordance with the publisher's policies. Please refer to any applicable terms of use of the publisher.

\section{General rights}

Copyright for the publications made accessible via the Queen's University Belfast Research Portal is retained by the author(s) and / or other copyright owners and it is a condition of accessing these publications that users recognise and abide by the legal requirements associated with these rights.

Take down policy

The Research Portal is Queen's institutional repository that provides access to Queen's research output. Every effort has been made to ensure that content in the Research Portal does not infringe any person's rights, or applicable UK laws. If you discover content in the Research Portal that you believe breaches copyright or violates any law, please contact openaccess@qub.ac.uk. 


\title{
Borenium ionic liquids as catalysts for Diels-Alder reaction: tuneable Lewis superacids for catalytic applications
}

\author{
K. Matuszek, ${ }^{a}+$ S. Coffie, ${ }^{b+}$ A. Chrobok, ${ }^{a *}$ and M. Swadźba-Kwaśny ${ }^{b *}$
}

\begin{abstract}
Ionic liquids based on tricoordinate borenium cation were used for the first time as Lewis acidic catalysts for a model Diels-Alder reaction. The conversion of dienophile was successfully correlated with the Gutmann Acceptor Numbers values of ionic liquids. Borenium ionic liquids exceeded the performance of catalysts reported in the literature.
\end{abstract}

Borenium cations are tricoordinate, strongly Lewis acidic species, with acidity of the free $p$ orbital of boron enhanced by the positive charge. ${ }^{1,2,3}$ They have been used as homogenous Lewis acidic catalysts in a range of reactions, including borylations, transformations involving carbonyl groups, or as components of frustrated Lewis pairs. ${ }^{1,3,4}$ Nearly all of these studies were carried out in aprotic organic solvents.

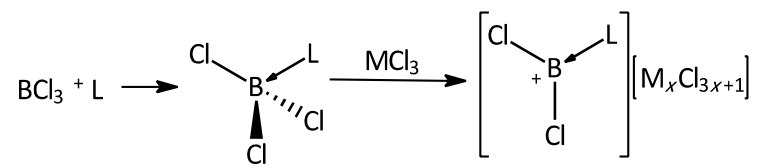

Scheme 1 Synthesis of borenium ionic liquids, $L=1$-methylimidazole (mim), 4 picoline (4pic), dimethylacetamide (dma), trioctylphosphine ( $\left.P_{888}\right)$ trioctylphosphine oxide $\left(\mathrm{P}_{888} \mathrm{O}\right), \mathrm{M}=\mathrm{Al}$ or $\mathrm{Ga}, \mathrm{x}=1$ or 2 .

Recently, ionic liquids based on borenium cations have been reported. They were prepared in a two-step process: the formation of a tetracoordinate trichloroborane adduct, followed by the chloride abstraction under solventless conditions (Scheme 1). For a range of ligands, homogenous ionic liquids were obtained as products. $^{5}$ The ionic liquid environment enabled the measurement of Lewis acidity of borenium cations under solventless conditions. Gutmann Acceptor Numbers were extremely high, up to $A N=182$ : this was attributed to the positive charge on the boron centre,

a. Department of Chemical Organic Technology and Petrochemistry, Silesian University of Technology, Krzywoustego 4, 44-100 Gliwice, Poland, e-mail: Anna.Chrobok@polsl.pl

b. School of Chemistry and Chemical Engineering, Queen's University of Belfast, Belfast, BT9 5AG, United Kingdom, e-mail: m.swadzba.kwasny@qub.ac.uk + Both authors contributed equally to this work.

Electronic Supplementary Information (ESI) available: [details of the borenium ILs synthesis and NMR spectra of Diels-Alder cycloadducts]. See DOI: $10.1039 / x 0 \times x 00000 x$ combined with lack of solvation from a molecular solvent in neat ionic liquid.

AN values have been reported to correlate with catalytic activity of strong boron Lewis acids, such as $\mathrm{BBr}_{3}$ or $\mathrm{Bl}_{3}(\mathrm{AN}<120){ }^{6}$ Nevertheless, in claiming practical importance of Lewis superacidity of borenium ionic liquid, it was crucial to establish that such correlation holds also for extremely high AN values. In order to compare the new borenium systems to known catalysts, a well-established model reaction was required. DielsAlder cycloaddition was selected, being a popular model reaction to test the catalytic performance of Lewis acids. ${ }^{7}$

Diels-Alder reaction is a powerful tool in organic chemistry, allowing for a one-step synthesis of six-membered carbocycles from a diene and a dienophile (Scheme 2). Lewis acids catalyse Diels-Alder reactions by coordination to the dienophile, influencing both the reaction rate and the selectivity to endo:exo or ortho/para isomers. ${ }^{8} \mathrm{~A}$ range of Lewis acids have been studied to date, from simple Lewis acidic halides $\left(\mathrm{ZnCl}_{2}\right.$, $\mathrm{BF}_{3}, \mathrm{SnCl}_{4}$ or $\mathrm{AlCl}_{3}$ ), through chiral borenium cations, ${ }^{9}$ to ionic liquids. Among Lewis acidic ionic liquids, ${ }^{10,11,12}$ chloroaluminate(III) systems were the most active catalysts reported to date. ${ }^{12}$

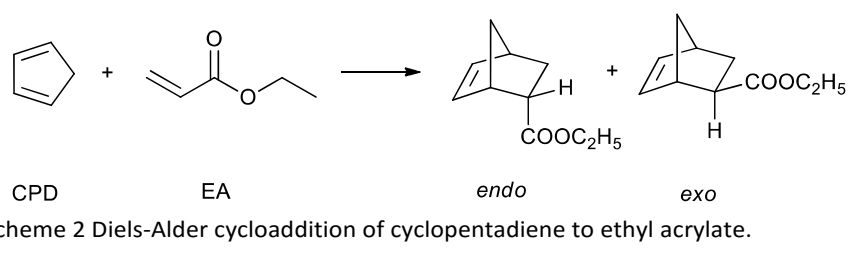

Borenium ionic liquids, of a general structure shown in Scheme 1 , were prepared according to the literature. ${ }^{5} \mathrm{~A}$ range of ligands on the boron centre was tested: 4-picoline (4pic), 1methylimidazol $(\mathrm{mim}), \quad$ trioctylphosphine $\left(\mathrm{P}_{888}\right)$, trioctylphosphine oxide $\left(\mathrm{P}_{888} \mathrm{O}\right)$ and dimethylacetamide (dma). Chlorometallate anions, formed through halide abstraction, were either neutral: $\left[\mathrm{AlCl}_{4}\right]^{-}$or $\left[\mathrm{GaCl}_{4}\right]^{-}$, or Lewis acidic: $\left[\mathrm{Al}_{2} \mathrm{Cl}_{7}\right]^{-}$ or $\left[\mathrm{Ga}_{2} \mathrm{Cl}_{7}\right]^{-}$. Gutmann Acceptor Number values (unless reported in the literature $)^{5}$ were measured following the approach adapted for ionic liquids, ${ }^{13}$ with triethylphosphine oxide as the 
${ }^{31} \mathrm{P}$ NMR spectroscopic probe. For ionic liquids based on chloroaluminate(III) anions, there two ${ }^{31} \mathrm{P}$ NMR signals were recorded, one within the range corresponding to chloroaluminate(III) anions ( $\left.\mathrm{AN}_{\mathrm{an}}=90-98\right)$, and another to the borenium cation $\left(A N_{c a t}>120\right)$. For ionic liquids with chlorogallate(III) anions, only one strong signal was detected, in the region corresponding to the borenium cation, $\mathrm{AN}_{\text {cat }}$. This was in agreement with the literature findings. ${ }^{5}$ As a general rule, Lewis acidity of borenium cations associated with monomeric anions, $\left[\mathrm{MCl}_{4}\right]^{-}$, was lower than that of identical cations, but associated with dimeric anions, $\left[\mathrm{M}_{2} \mathrm{Cl}_{7}\right]^{-}$. Monomeric cations are stronger coordinating, which resulted in stronger cation-anion interactions, and consequently weaker Lewis acidity - this is also in agreement with prior observations. ${ }^{5}$

The reaction of cyclopentadiene with ethyl acrylate (Scheme 2) was used as a model Diels-Alder transformation. The reaction was carried out solventless, with very small amount of ionic liquid catalyst dissolved in neat reactants (with diene in excess). ${ }^{14}$ Anticipating high activity of borenium ionic liquids, they were firstly tested at $0{ }^{\circ} \mathrm{C}$, at extremely low concentrations of $0.1 \mathrm{~mol} \%$. For comparison, using a mildly acidic chlorozincate(II) system, [choline] $\mathrm{Cl}-\mathrm{ZnCl}_{2}\left(\chi_{\mathrm{ZnCl}}=0.67\right), 10$ mol\% of ionic liquid was required to achieve ca. $90 \%$ conversion in $8 \mathrm{~min}$, at ambient temperature. ${ }^{10}$ Even highly acidic chloroaluminate(III) and chlorogallate(III) systems ( $\left.\chi_{\mathrm{MCl}}=0.67\right)$, required $5 \mathrm{~mol} \%$ to reach $99 \%$ conversion in $5 \mathrm{~min}$, also at ambient temperature. ${ }^{15}$

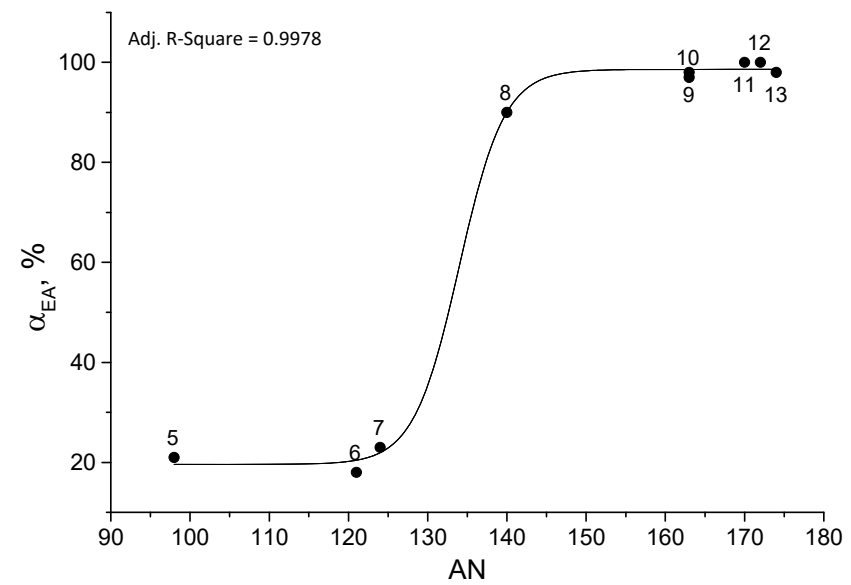

Figure 1 Conversions in Diels-Alder cycloaddition of cyclopentadiene to ethyl acrylate, catalysed with 0.10 mol\% of Lewis acidic ionic liquids vs. AN values of the catalysts, numbers on the figure are identical as catalysts number in table 1. $16 \mathrm{mmol}$ ), ice bath, 5 min, $1500 \mathrm{rmm}$, conversion determinet by $\mathrm{GC}$.

Conversion of the dienophile at $0.10 \%$ loading of borenium ionic liquid was plotted against $\mathrm{AN}_{\text {cat }}$ values (Figure 1). It appears that there is a Boltzmann sigmoidal correlation between the AN values and the dienophile conversion. A very good correlation was found with the experimental data $\left(R^{2}=0.9978\right)$, despite using extremely small catalyst amount, which could be expected to bear significant measurement error. This suggests that the main catalytic process involves the borenium cation, irrespective of the Lewis acidic or neutral nature of the anion. It also showcases that Diels-Alder cycloaddition is very sensitive to Lewis acid strength, making it an excellent model system. ${ }^{7}$
However, by altering the anion and/or the ligand on the boron centre - Lewis acidity and thus catalytic activity can be finetuned. The endo:exo selectivities remained constant (94:6 96:4), irrespective of the ionic liquid used.

The influence of catalyst loading ( 0.10 to $1.00 \mathrm{~mol} \%)$ on conversion and selectivity was studied using one of the less Lewis acidic ionic liquid, $\left[\mathrm{BCl}_{2}(4 \mathrm{pic})\right]\left[\mathrm{GaCl}_{4}\right]\left(\mathrm{AN}_{\mathrm{cat}}=121\right)$. Even this system proved to be very active, with $\geq 0.50$ mol\% loading sufficient to achieve full conversion within 5 min (Figure 2). Endo:exo selectivities remained unaffected by the catalyst concentration (94:6).

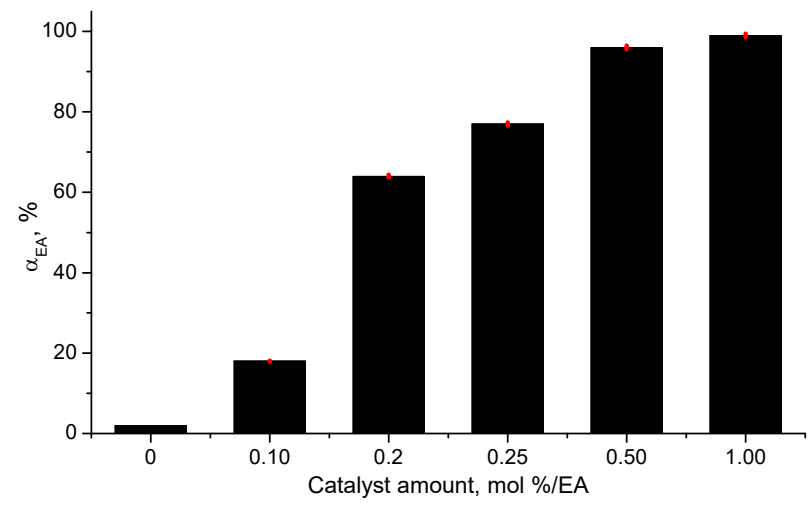

Figure 2. The influence of catalyst loading on the conversion of ethyl acrylate Reaction conditions: cyclopentadiene $(1.586 \mathrm{~g}, 24 \mathrm{mmol})$, ethyl acrylate $(1.602 \mathrm{~g}$ determined by $\mathrm{GC}$.

Table 1 Conversions and endo:exo selectivities in Diels-Alder cycloaddition of cyclopentadiene and ethyl acrylate, catalysed with borenium ionic liquids, $\mathrm{AlCl}_{3}$ and chloroaluminate(III) ionic liquids, along with corresponding AN values.

\begin{tabular}{|c|c|c|c|c|}
\hline No & Catalyst & Amount, mol\% & AN & $\alpha_{\mathrm{EA}}, \%$ \\
\hline \multirow{2}{*}{1} & \multirow{2}{*}{$\mathrm{AlCl}_{3}$} & 0.10 & \multirow{2}{*}{$96^{18}$} & 6 \\
\hline & & 0.25 & & 100 \\
\hline 2 & {$\left[\mathrm{C}_{2} \mathrm{mim}\right] \mathrm{Cl}$} & 0.50 & - & 3 \\
\hline 3 & {$\left[\mathrm{C}_{2} \mathrm{mim}\right]\left[\mathrm{AlCl}_{4}\right]$} & 0.50 & - & 3 \\
\hline \multirow{2}{*}{4} & \multirow{2}{*}[\mathrm{C}_{2}\mathrm{mim}]{$\left[\mathrm{Al}_{2} \mathrm{Cl}_{7}\right]$} & 0.10 & \multirow{2}{*}{$96^{11}$} & 3 \\
\hline & & 0.25 & & 99 \\
\hline \multirow{2}{*}{5} & \multirow{2}{*}[\mathrm{BCl}_{2}(\mathrm{P}_{888})]{$\left[\mathrm{Al}_{2} \mathrm{Cl}_{7}\right]$} & 0.10 & \multirow{2}{*}{$98^{5}$} & 21 \\
\hline & & 0.50 & & 100 \\
\hline \multirow{2}{*}{6} & \multirow{2}{*}[\mathrm{BCl}_{2}(4\mathrm{pic})]{$\left[\mathrm{GaCl}_{4}\right]$} & 0.10 & \multirow{2}{*}{$121^{5}$} & 18 \\
\hline & & 0.50 & & 97 \\
\hline \multirow{2}{*}{7} & \multirow{2}{*}[\mathrm{BCl}_{2}(4\mathrm{pic})]{$\left[\mathrm{AlCl}_{4}\right]$} & 0.10 & \multirow{2}{*}{$124^{5}$} & 23 \\
\hline & & 0.50 & & 100 \\
\hline \multirow[b]{2}{*}{8} & \multirow[b]{2}{*}[\mathrm{BCl}_{2}(4\text{pic})]{$\left[\mathrm{Ga}_{2} \mathrm{Cl}_{7}\right]$} & 0.10 & \multirow[b]{2}{*}{$140^{5}$} & 90 \\
\hline & & 0.20 & & 100 \\
\hline 9 & {$\left[\mathrm{BCl}_{2}(\mathrm{dma})\right]\left[\mathrm{Al}_{2} \mathrm{Cl}_{7}\right]$} & 0.10 & $163^{5}$ & 98 \\
\hline 10 & {$\left[\mathrm{BCl}_{2}(\mathrm{dma})\right]\left[\mathrm{Ga}_{2} \mathrm{Cl}_{7}\right]$} & 0.10 & $163^{5}$ & 97 \\
\hline 11 & {$\left[\mathrm{BCl}_{2}(4 \mathrm{pic})\right]\left[\mathrm{Al}_{2} \mathrm{Cl}_{7}\right]$} & 0.10 & $170^{5}$ & 100 \\
\hline 12 & {$\left[\mathrm{BCl}_{2}(\mathrm{mim})\right]\left[\mathrm{Ga}_{2} \mathrm{Cl}_{7}\right]$} & 0.10 & $172^{5}$ & 100 \\
\hline 13 & {$\left[\mathrm{BCl}_{2}(\mathrm{mim})\right]\left[\mathrm{Al}_{2} \mathrm{Cl}_{7}\right]$} & 0.10 & $174^{5}$ & 98 \\
\hline
\end{tabular}

Reaction conditions: cyclopentadiene $(1.586 \mathrm{~g}, 24 \mathrm{mmol})$, ethyl acrylate ( $1.602 \mathrm{~g}$, $16 \mathrm{mmol}$ ), ice bath, $5 \mathrm{~min}, 1500 \mathrm{rpm}$, conversion and endo:exo ratio determined by GC.

All borenium ionic liquids tested in Diels-Alder cycloaddition, the corresponding $\mathrm{AN}_{\text {cat }}$ values, conversions at $0.10 \%$ catalyst loadings, catalyst loadings required to achieve full conversions 
within $5 \mathrm{~min}$, and corresponding endo:exo selectivities are listed in Table 1.

For comparison, four experiments were carried out with benchmark catalysts (Table 1 ): $\mathrm{AlCl}_{3},\left[\mathrm{C}_{2} \mathrm{mim}\right] \mathrm{Cl},\left[\mathrm{C}_{2} \mathrm{mim}\right]\left[\mathrm{AlCl}_{4}\right]$ and $\left[\mathrm{C}_{2} \mathrm{mim}\right]\left[\mathrm{Al}_{2} \mathrm{Cl}_{7}\right]$, where $\left[\mathrm{C}_{2} \mathrm{mim}\right]^{+}$is 1-ethyl-3methylimidazolium cation. $\mathrm{AlCl}_{3}$ is a Lewis acid ( $\mathrm{AN}=96$ ), commonly used in Lewis acid catalysis. The $\left[\mathrm{C}_{2} \mathrm{mim}\right]\left[\mathrm{Al}_{2} \mathrm{Cl}_{7}\right]$ ionic liquid is also a strong Lewis acid ( $\mathrm{AN}=96)$, with acidity arising from the dimeric $\left[\mathrm{Al}_{2} \mathrm{Cl}_{7}\right]^{-}$anion, and has been used in numerous catalytic applications. ${ }^{16,17,18}$ In contrast, $\left[\mathrm{C}_{2} \mathrm{mim}\right]\left[\mathrm{AlCl}_{4}\right]$ is considered to be neutral, and thus catalytically inactive. Finally, $\left[\mathrm{C}_{2} \mathrm{mim}\right] \mathrm{Cl}$ is a Lewis base due to the presence of chloride anion. Both benchmark Lewis acids: $\mathrm{AlCl}_{3}$ and $\left[\mathrm{C}_{2} \mathrm{mim}\right]\left[\mathrm{Al}_{2} \mathrm{Cl}_{7}\right]$, had negligible catalytic activity at $0.10 \%$ loading, but were catalytically active at a higher concentration (0.25\%). Neither the neutral chloroaluminate(III) ionic liquid, $\left[\mathrm{C}_{2} \mathrm{mim}\right]\left[\mathrm{AlCl}_{4}\right]$, nor the basic halide salt, $\left[\mathrm{C}_{2} \mathrm{mim}\right] \mathrm{Cl}$, were catalytically active, irrespective of concentration. In comparison, all borenium ionic liquids were catalytically active at $0.10 \%$ loading, which explicitly confirms that the catalytic activity originates from the borenium cation.

Identification of the actual catalytic species is a very complex task. Ionic liquid anions are known for their complex speciation, with various chlorometallate anions remaining in complex equilibria with each other (Eqn 1). ${ }^{17}$ Furthermore, solution studies on borocations with chlorometallate counterions reveal further complexity in speciation, due to ligand scrambling (Eqn 2). ${ }^{3}$ The same scrambling was indeed reported for borenium ionic liquids. ${ }^{5}$

$2\left[\mathrm{Ga}_{2} \mathrm{Cl}_{7}\right]^{-} \rightleftarrows\left[\mathrm{GaCl}_{4}\right]^{-}+\left[\mathrm{Ga}_{3} \mathrm{Cl}_{10}\right]^{-}$

(Eqn 1)

$\left[\mathrm{BCl}_{2} \mathrm{~L}\right]\left[\mathrm{AlCl}_{4}\right] \rightleftarrows \mathrm{BCl}_{3}+\left[\mathrm{AlCl}_{3} \mathrm{~L}\right]$

(Eqn 2)

In order to gain some insight into the identity of the main catalytic species, an ionic liquid, $\left[\mathrm{BCl}_{2}(4 \mathrm{pic})\right]\left[\mathrm{AlCl}_{4}\right]$ was dissolved in excess of dienophile, ethyl acrylate (EA), and studied by ${ }^{11} \mathrm{~B}$ and ${ }^{27} \mathrm{Al}$ NMR spectroscopy. The dominant ${ }^{11} \mathrm{~B}$ NMR signal shifted from $34 \mathrm{ppm}$ in neat ionic liquid (Figure 3a) corresponding to tricoordinate borenium cation, $\left[\mathrm{BCl}_{2}(4 \mathrm{pic})\right]^{+}$, to $6.4 \mathrm{ppm}$ in ethyl acrylate solution (Figure $3 \mathrm{~b}$ ) - corresponding to a tetracoordinate boronium cation, $\left[\mathrm{BCl}_{2}(4 \mathrm{pic})(\mathrm{EA})\right]^{+}$. The ${ }^{27} \mathrm{Al}$ NMR spectrum of neat $\left[\mathrm{BCl}_{2}(4 \mathrm{pic})\right]\left[\mathrm{AlCl}_{4}\right]$ features a broad signal at $102 \mathrm{ppm}$ with an upfield shoulder (Figure 4a). Broadening arises both from the viscosity of the neat ionic liquid and from dynamic equilibria, and the shoulder corresponds to the ligand scrambling product. The ${ }^{27} \mathrm{Al}$ NMR spectrum recorded in ethyl acrylate solution (Figure $4 \mathrm{~b}$ ) features a dominant sharp signal at $102 \mathrm{ppm}$ - characteristic of $\left[\mathrm{AlCl}_{4}\right]^{\text {, }}$, and a very weak and broader signal at $92 \mathrm{ppm}$, corresponding to $\mathrm{AlCl}_{3}$ with an $O$-donor, namely $\left[\mathrm{AlCl}_{3}(\mathrm{EA})\right]^{-}$. This demonstrates that the dienophile binds to the borenium cation and, despite its excess, to a very small extent it exchanges with chlorides in $\left[\mathrm{AlCl}_{4}\right]^{-}$. It must be pointed out that this is just an insight, and detailed studies must be carried out to reveal all possible catalytic species, especially when acidic $\left[\mathrm{M}_{2} \mathrm{Cl}_{7}\right]^{-}$anions would be considered.

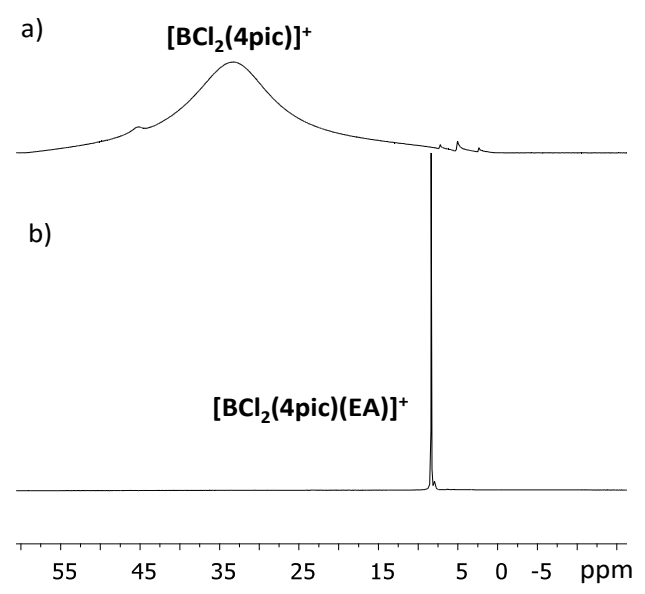

Figure $3{ }^{11} \mathrm{~B}$ NMR spectra of a) neat $\left[\mathrm{BCl}_{2}(4 \mathrm{pic})\right]\left[\mathrm{AlCl}_{4}\right]$, and b) solution of $\left[\mathrm{BCl}_{2}(4 \mathrm{pic})\right]\left[\mathrm{AlCl}_{4}\right]$ in ethyl acrylate $(\mathrm{EA})$. Both recorded with external $d_{6}$-DMSO lock.

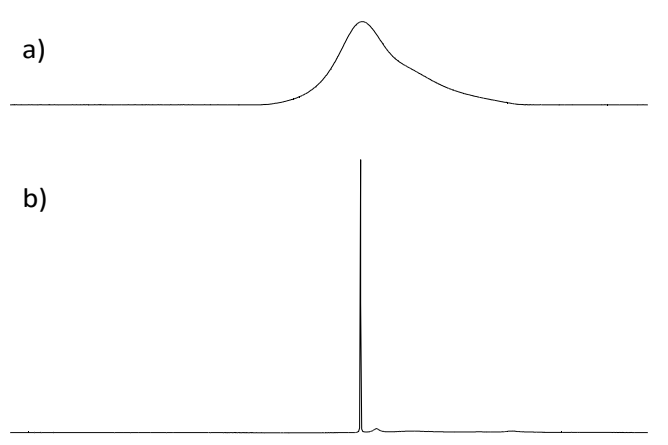

$\begin{array}{llllllllll}350 & 300 & 250 & 200 & 150 & 100 & 50 & 0 & -50 & \mathrm{ppm}\end{array}$

Figure $4{ }^{27} \mathrm{Al} \mathrm{NMR}$ spectra of a) neat $\left[\mathrm{BCl}_{2}(4 \mathrm{pic})\right]\left[\mathrm{AlCl}_{4}\right]$, and b) solution of $\left[\mathrm{BCl}_{2}(4 \mathrm{pic})\right]\left[\mathrm{AlCl}_{4}\right]$ in ethyl acrylate (EA). Both recorded with external $d_{6}$-DMSO lock.

To test the robustness of borenium ionic liquid catalysts, a substrate scope study was carried out (Table 2). A range of Diels-Alder cycloadditions, utilizing various dienes and dienophiles (Figure 5), were carried out in the presence of 0.20 mol\% of $[\mathrm{BCl} 2(\mathrm{mim})][\mathrm{Al} 2 \mathrm{Cl} 7]$ per dienophile. Full conversions were obtained after 5-15 min reaction times at $0{ }^{\circ} \mathrm{C}$, with isolated yields ranging from 86 to $93 \%$. Cyclopentadiene reacted with dienophiles: diethyl maleate, methyl acrylate, methacrolein and methyl vinyl ketone, to give full dienophile conversion in $5 \mathrm{~min}$ at $0{ }^{\circ} \mathrm{C}$, with very high endo selectivities, which is typical for Lewis acid catalysed reactions. Dienophiles reacting with isoprene and cyclohexadiene reached full conversion in $15 \mathrm{~min}$ at $0{ }^{\circ} \mathrm{C}$, which again points to a very high activity of the catalyst. Moreover, adducts of isoprene and methyl acrylate or methyl vinyl ketone formed a nearly pure endo isomer (endo:exo ratio of 95:5). Only in reaction of cyclohexadiene with methyl vinyl ketone, slightly lower endo selectivities was recorded (83:17). No other products (e.g. haloborated side-products) have been detected. 
Table 2 Diels-Alder reaction of various dienes with dienophiles in the presence of $\left[\mathrm{BCl}_{2}(\mathrm{mim})\right]\left[\mathrm{Al}_{2} \mathrm{Cl}_{7}\right]$ as catalyst.

\begin{tabular}{cccccc}
\hline Diene & Dienophile & Product & $\begin{array}{c}\alpha \text { dienophile, } \\
\%\end{array}$ & $\begin{array}{c}\text { Isolated } \\
\text { yield, } \%\end{array}$ & $\begin{array}{c}\text { Isomer } \\
\text { ratio, } \%\end{array}$ \\
\hline 1 & a & 1a & 100 & 92 & $98: 2$ \\
1 & b & 1b & 98 & 93 & $95: 5$ \\
1 & c & 1c & 100 & 91 & $98: 2$ \\
1 & d & 1d & 99 & 92 & $94: 6$ \\
2 & b & 2b & 100 & 91 & $95: 5$ \\
2 & d & 2d & 100 & 90 & $95: 5$ \\
3 & d & 3d & 99 & 90 & $83: 17$ \\
\hline
\end{tabular}

Reaction conditions: diene ( $24 \mathrm{mmol}$ ), diepnophile ( $16 \mathrm{mmol}$ ), catalyst loading 0.20 mol\% of $\left[\mathrm{BCl}_{2}(\mathrm{mim})\right]\left[\mathrm{Al}_{2} \mathrm{Cl}_{7}\right]$ per diepnophile; ice bath, 5-15 min, $1500 \mathrm{rpm}$.

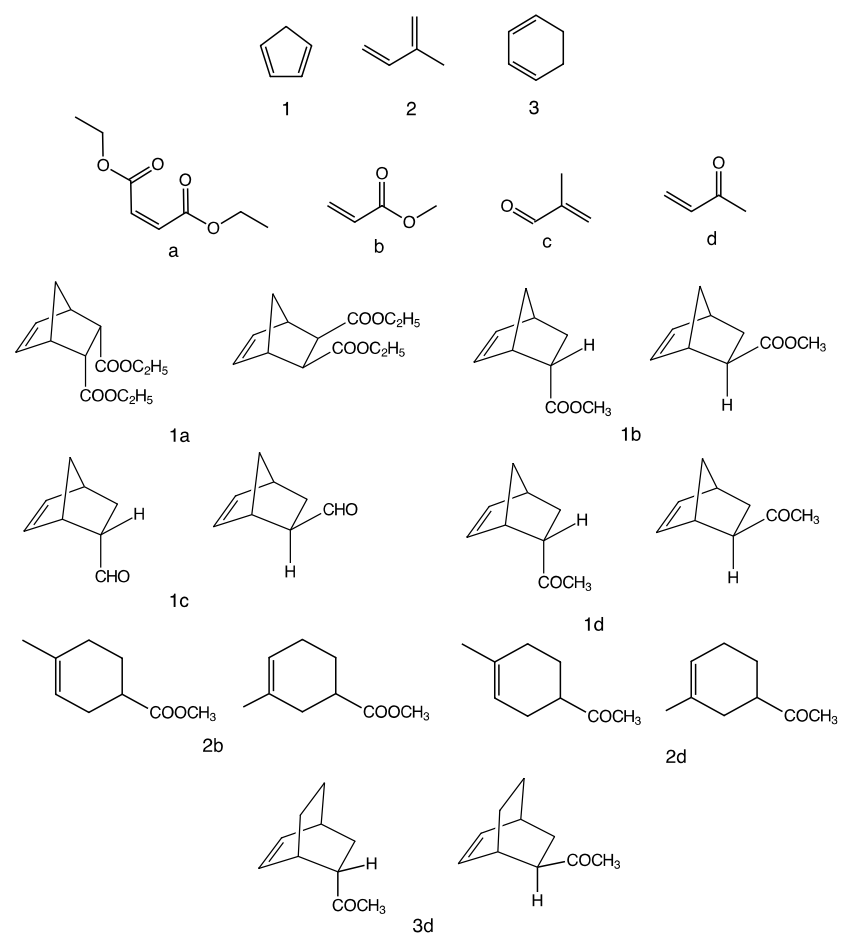

Figure 5 Dienes and dienophiles used in Diels-Alder reaction.

In conclusion, Lewis superacidity of borenium ionic liquids, previously postulated from high AN values, was confirmed in exceptionally high catalytic activity in Diels-Alder reaction. Due to their ionic liquid form, it the use of solvent was avoided; small amounts of ionic liquid were dissolved into the reactant mixture, thereby avoiding 'levelling effect' from the solvent and lowering potential environmental impact. At very low catalyst concentration $(0.10 \mathrm{~mol} \%)$, good correlation between the Lewis acidity strength (AN values) and the conversion of the dienophile was observed. Upon increasing the catalyst loading to $0.20-0.50 \mathrm{~mol} \%$, full conversions were reached in $5 \mathrm{~min}$ at 0 ${ }^{\circ} \mathrm{C}$. Endo:exo selectivities were consistently high, unaffected by the catalyst $A N$ value or loading. Borenium ionic liquids were catalytically active against a wide substrate scope, demonstrating robustness of these systems.

Anions in borenium ionic liquids were either monomeric and thus neutral, $\left[\mathrm{MCl}_{4}\right]^{-}$, or dimeric and thus Lewis acidic, $\left[\mathrm{M}_{2} \mathrm{Cl}_{7}\right]^{-}$. This could potentially raise concern as to the nature of the catalytic species. This issue was addressed on several levels: (i) catalytic activity was found to correlate to $\mathrm{AN}_{\text {cat }}$ values, irrespective of the anion, (ii) borenium ionic liquids were active at $0.10 \%$ loading, at which Lewis chloroaluminate(III) ionic liquid, $\left[\mathrm{C}_{2} \mathrm{mim}\right]\left[\mathrm{Al}_{2} \mathrm{Cl}_{7}\right]$, was inactive, and (iii) borenium ionic liquids with $\left[\mathrm{MCl}_{4}\right]^{-}$anions were catalytically active, whereas $\left[\mathrm{C}_{2} \mathrm{mim}\right]\left[\mathrm{AlCl}_{4}\right]$ was inactive, irrespective of the loading.

\section{Acknowledgements}

AC and KM would like to acknowledge the National Science Centre of Poland for grant no. UMO-2012/06/M/ST8/00030. SC would like to thank the COST Action (CM1206 EXIL - Exchange on lonic Liquids) for supporting STSM in Silesian University of Technology, Gliwice, Poland.

\section{Notes and references}

1 T. S. De Vries, A. Prokofjevs and E. Vedejs, Chem. Rev., 2012, $112,4246$.

2 W. E. Piers, S. C. Bourke and K. D. Conroy, Angew. Chem. Int. Ed., 2005, 44, 5016.

3 M. J. Ingleson, Top. Organomet. Chem., 2015, 49, 39.

4 D. W. Stephan, J. Am. Chem. Soc., 2015, 137, 10018.

5 S. Coffie, J. M. Hogg, L. Cailler, A. Ferrer-Ugalde, R. W. Murphy, J. D. Holbrey, F. Coleman and M. Swadźba-Kwaśny, Angew. Chem. Int. Ed., 2015, 54, 14970.

6 M. A. Beckett, G. C. Strickland, J. R. Holland and K. S. Varma, Polymer, 1996, 37, 4629.

7 G. Hilt and A. Nödling, Eur. J. Org. Chem., 2011, 2011, 7071.

8 F. Fringuelli and A. Taticchi, Diels-Alder reaction. Selected practical methods, John Wiley \& Sons, New York, 2002

9 E. J. Corey, T. Shibata and T. W. Lee, J. Am. Chem. Soc., 2002, 124, 3808.

10 A. P. Abbott, G. Capper, D. L. Davies, R. K. Rasheed and V. Tambyrajah, Green Chem., 2002, 4, 24.

11 K. Erfurt, I. Wandzik, K. Z. Walczak, K. Matuszek and A. Chrobok, Green Chem., 2014, 16, 3508.

12 C. Chiappe, M. Malvaldi and C. S. Pomelli, Green Chem., 2010, 12, 1330.

13 J. Estager, A. A. Oliferenko, K. R. Seddon and M. SwadźbaKwaśny, Dalton Trans., 2010, 39, 11375.

14 Diels-Alder reaction: The dienophile $(16 \mathrm{mmol})$ and the borenium ionic liquid ( $0.1 \mathrm{~mol} \%$ per dienophile) were placed in a two-necked round-bottomed flask equipped with septum, argon balloon, ice-bath and stirring bar. The diene $(24 \mathrm{mmol})$ was added dropwise to the vigorously stirred (1500 rpm) reaction mixture. The reaction was carried out for 5-15 min, and then quenched with a few drops of water. Dichloromethane $(2 \mathrm{ml})$ and decane (internal standard) were added. Conversion of ethyl acrylate and selectivity were measured by GC. Products were purified by column chromatography (silica gel, $100 \%$ of chloroform as eluent).

15 C. W. Lee, Tetrahedron Lett., 1999, 40, 2461.

16 H.-P. Steinrück and P. Wasserscheid, Catal. Lett., 2014, 145, 380.

17 J. Estager, J. D. Holbrey and M. Swadźba-Kwaśny, Chem. Soc. Rev., 2014, 43, 847.

18 K. Matuszek, A. Chrobok, P. Latos, M. Markiton, K. Szymanska, A. Jarzebski and M. Swadzba-Kwasny, Catal. Sci. Technol., 2016, 6, 8129. 